\title{
MONGOLIA'S ECONOMIC DEVELOPMENT IN THE CONTEXT OF NORTHEAST ASIAN ECONOMIC COOPERATION
}

\section{By Peter Scram}

In this era of global commercialization, economic cooperation among countries no longer takes the form of coordinating or integrating their national economic plans through bilateral trade agreements and the like. Instead, countries now cooperate mostly to establish a better framework for international commercial relations and to improve their comparative advantages in international trade. Taking advantage of such opportunities has become the task for commercial enterprise, however owned. Creating or improving them remains a government function whenever externalities limit the effectiveness of market forces. Differences between commercial and social costs as well as benefits affect in particular various facets of infrastructural development. Intergovernmental cooperation concerning e.g., transportation and communications, pollution control, and the transfer of technology generally figure prominently in this context.

My aim in this paper is review the grounds for international commercial and governmental cooperation with specific reference of Mongolia. It seems only fair "to warn you in advance that I come to this task as an "outsider" who until recently was more familiar with the conditions in China and in Russia. Your invitation to participate in this conference struck me as a challenge to learn about Mongolia, its development, and its relations to Northeast Asia as well as the rest of the world. I do hope that the results justify my effort.

My presentation will focus on a few major opportunities and projects for commercial and governmental cooperation. The omission of many minor ones does not mean that they should be ignored as unimportant. In fact, it may well turn out that a multitude of small ventures will be most effective in promoting Mongolia's future development and integration with the rest of the world. They have been elsewhere.

\section{Mongolia's Comparative Advantages and Disadvantages}

Mongolia's economic situation and position vis-a-vis the rest of the world can be summarized simply in a few paragraphs. It is one of the larger countries in terms of territory and ranks among the smaller ones in terms of population. It's extremely low population density relates to the fact that its geographic charac- 
teristics made for nomadic animal herding rather than for sedentary farming as the traditional form of life and work in the countryside. Other activities, including commerce with the rest of the world, added relatively little to this form of subsistence economy.

Any movement away from such a state - in particular the development of urban living and industrial production -had to make Mongolia highly foreign trade dependent. The domestic market was not large enough to induce cost effective production in most mining and manufacturing. Moreover, climatic conditions made sedentary farming activities- both crop growing and animal husbandry - a marginal, risky business which would not flourish without subsides. Mongolia's urbanization and industrialization thus depended critically on foreign demand for its new industrial products and on foreign supply for many urban consumer goods and most capital goods as well.

The Soviet Union, which had been instrumental in initiating this development, together with the countries of the CMEA bought and sold most of those exports and imports. The collapse of the Soviet system affected trade relations negatively and forced Mongolia to find additional markets for its exports and imports, on different terms, which changed the values of many past activities, old or new.

Since then, extensive animal husbandry has remained the mainstay of rural subsistence economy and has become more prevalent once again during the transition from plan to market. Moreover, it is one of the activities that clearly offer actual as well as potential advantages and thus opportunities for export oriented specialization. Animal products such as wool and cashmere are already well established in international markets. Other products, e.g., skins and hides as well as meat and diary products can be made more competitive (although the latter would be supplied disproportionately by sedentary operations). Furthermore, state-of-the-art processing facilities can be developed to add value to all these primary products.

In contrast, intensive animal husbandry and crop growing have been limited to a very small share of the land in a few relatively favorable locations. Both have flourished during the 1980's because they were subsidized as import substitution activities, to meet urban food requirements. With the decline in CMEA trade and the loss of protection and subsidies, sedentary farming has diminished greatly. What remains to be established, however, is whether it is an inherently inferior and thus unsustainable activity or one that is restorable with appropriate technical renovations and. organizational/managerial reforms. 
In addition to ample grazing lands, Mongolia possesses extensive forested regions which provide the basis for a timber industry. As of now, most of the output of this industry is being exported. Opportunities for further wood processing have yet to be developed.

Beneath the grazing lands and forests, Mongolia's territory contains large deposits of minerals and metals, notably coal, copper and fluorspar. Their accelerated exploitation, also mainly during the 1980's, gave rise to a more rapid urbanization that absorbed much of the increase in total population. Such agglomeration occurred particularly in a few mining areas. Most of the output of coal, like that of food crops, serves to support this urban industrial sector, directly or indirectly, i.e., through electric power generation. In contrast, copper (whose concentration is extremely energy consumptive), fluorspar, and other mining products-especially gold-have become important exports. Their variety, volume, and quality can be increased as well, and further processing may well become advantageous in the right circumstances.

For the time being, many mining activities remain negatively affected by the decline in the trade with former CMEA countries, which also makes spare parts for existing equipment difficult to obtain. For the future, however, the prospects look much brighter. Not only are changes in technology pending or likely. It also appears that the exploration of Mongolia's subterranean resources is far from complete. The recent discoveries of new coal and oil deposits in particular promise imminent gains in energy output and suggest that there may be much more to look for and forward to.

Mongolia's most consequential disadvantages derive from its landlocked location. Wedged between China and Russia, it sits on the peripheries of those two countries, far removed from their centers of economic development. Its very low population density and nomadic subsistence economy account for the fact that its internal transport and communications system is extremely underdeveloped. The prevalence of unimproved roads makes it rather difficult and costly to move any commodity, thus hampering internal as well as international trade.

The railroads came to Mongolia from the Russian side, as spurs of the Tran Siberian Railroad to Ulaanbaatar and to Choybalsan. With local extensions, these lines tied the newly emerging industrial sector to the Soviet economy, as did several other roads to the north. The Ulaanbaatar Railroad eventually connected with the Chinese system at Zamyn Uud, thereby completing the modernization of the traditional trade route through Siberia. But hardly any other major road exited to China. To this day, the Ulaanbaatar Railroad remains the principal 
transit route, and Mongolia's access to China and the world beyond is thus restricted or circuitous, detouring via the Transsiberian Railroad. It is further complicated by the fact that Russia's and China's railroad gages do not match. Transshipment and undercarriage adjustment are both times consuming and costly, in spite of technical improvements made recently with Japanese funding.

In response to the termination of CMEA trade and Russia's economic decline, Mongolia had to reorient its trade more toward China, the other East Asian countries, and generally the Pacific side. Such a change in geographic direction affected the use of the Ulaanbaatar Railroad and no doubt posed handling capacity problems for China. Nevertheless, China accommodated this need, eventually granting Mongolia transit access to the port of Tianjin. Cooperation for Development

In such circumstances, Mongolia serves its interest in economic development when it focuses on exploiting its comparative advantages in mining and in extensive animal husbandry. To diversify, increase, and improve the production of those industries, it has to import more appropriate technology. To bring their products to markets abroad, it has to access and transit neighboring countries. For all those purposes, it not only has to develop its internal transportation and communications network but also has to link it more extensively to foreign systems. Its integration into the global economy thus necessitates cooperation with its neighbors and with everyone else who becomes involved in any of the facets of this process.

Cooperation between Mongolia and others-whether countries or firms- is a "two- way street," of course. It needs to serve the interests of all if all are to agree to a project and commit resources to its realization. Cooperators may expect to derive benefits from its completion for a wide variety of reasons, ranging from altruistic to self-seeking in one dimension, for example. All are going to commit resources on the strength of such interests, given their resource limitations.

Cooperation between Mongolia and others may simply take the form of coordinated domestic (internal) commitments to interdependent projects of mutual benefit, starting with tariffs and visas. Cooperation in this form appears to become characteristic of Mongolia's relations with China and Russia, notably in transportation and communication. Agreements on transit routes, other network connections, and their reciprocal uses are relevant examples. Unfortunately, the realization of such joint projects usually poses problems for the Mongol side because it evidently is short of the necessary means. Its gross 
national saving (GNS) has averaged 19 percent of gross national product (GNP) since 1993, far less than the savings rate in most rapidly industrializing economies of the Far East. ${ }^{1}$ Yet even if this rate could be doubled, the total ingestible funds would remain severely limited by the small sizes of Mongolia's total population and product relative to its territorial size. Economic cooperation therefore is unlikely to proceed very far in the absence of foreign investment and technical assistance inside Mongolia.

Such inputs have been forthcoming in considerable amounts. Mongolia's gross domestic investment (GDI) has averaged 25 percent of GDP since 1993, the implied foreign contributions averaging 6 percent of GDP since then. ${ }^{2}$ The principal national contributor has been Japan, which joined Asian Development Bank (ADB) and the World Bank (WB) as primary sources of support. Japan has become the most important provider of official grants of Mongolia, accounting for 58.4 percent of all grants during 1992-96. most of them destined for infrastructural projects. ${ }^{3}$ Its disbursements of medium-and long-term loans, which constituted 23.7 percent of all official loans during 1992-96, ranked second to those of the ADB (at 33.8 percent) and ahead of those of the WB (at 19.9 percent). All other countries and international institutions made much more limited contributions, ${ }^{4}$ except for the Enhanced Structural Adjustment Facility provided by the International Monetary Fund (IMF).

During the years 1991-96, Mongolia received altogether close to $\$ 1.2$ billion in loans, credit, grants-in-aid, and technical assistance. The contributors of this development support have met annually with Mongolia at donor conferences sponsored by the United Nations Development Program (UNDP), Japan, and the World Bank. The meetings have served to generate and coordinate awards as well as to check on their uses. The sixth such meeting of October 1997 raised pledges of $\$ 256$ million for 1998, including 30 percent in the form of grants and 70 percents as soft loans..$^{5}$ the indications are that Mongolia may have difficulties absorbing all of the pledged support.

In contrast, commercial interest in Mongolia has been much more reserved. Commercial loans added significantly to the official support only during 1992, when they helped in particular to renovate the copper mine.$^{6}$ foreign commercial direct investment came forth in very small amounts during most years. By implication, foreign firms in Northeast Asia and elsewhere seem to have been unimpressed until recently by the opportunities which Mongolia offers. Changes in mining legislation in particular and progress with the privatization of most state owned enterprises begin to attract this attention now. 


\section{Cooperative Projects}

The preceding comments delineate opportunities for cooperative commercial and official ventures. In instances of evident comparative advantage, businesses can be counted on to make appropriate resource commitments on their own. Whenever disadvantages need to be overcome in this context, however, complementary governmental action seems to be unavoidable. The mix of such involvements obviously depends on the balance of prospective benefits and costs in each case. In the following, a few projects will be reviewed which display cooperation among governments, international institutions, and firms on a variety of patterns.

Oil Extraction. The limited exploration and development of oil resources in the past have left Mongolia import dependent for all petroleum products until now. In the, absence of domestic refinery capacity, that situation is not going to change soon. However, recent initiatives at cooperation between the government and foreign oil exploration companies have improved the prospects for crude oil production and exports. The IMF anticipated that this development could begin in $1996 .{ }^{7}$ The Far Eastern Economic Review reported on 29 January 1998 that it" . . . already contributes around $\$ 800,000$ a year to the Mongolian budget, "and it noted in addition that

... In December, the Mongolian Oil Board approved a production-sharing agreement with the Canadian company Manpower Petroleum. The company will invest around $\$ 10$ million in two blocks and drill six test wells.

American company Soco, operating as Sotamo (Soco Tamsag Mongol), has invested more than $\$ 30$ million in two exploration blocks. This year Sotamo will broaden its operations over several thousand square kilometers with another $\$ 21.4$ million of investment.

Soco, which is expected to begin regular exports, also plans a 100kilometre pipeline from its Tamsag operation in Eastern Mongolia to the border with China. Tamsag is far from railways and roads, but just across the Chinese border there is railway access to spare refining capacity. ${ }^{8}$

The railway access referred to seems to be at Yirshi, the railhead in Inner Mongolia to the east of Tamsag. For the time being, oil is being trucked from Tamsag southwest over $300 \mathrm{~km}$ via a new border at Bichig in Siihbaatar aimag into China"9 which is becoming more and more dependent on imports of oil as well. 
Transportation in the area will be enhanced further by $1.000 \mathrm{~km}$ road, built with ADB support, from Ulaanbaatar via Ondorhaan to Dornod aimag, with extensions north to Russia and east to China, the latter crossing the Tamsag oil field, ${ }^{10}$ presumably en route to Yirshi. In addition, there plans to build a railroad between Yirshi and Choybalsan, presumably via Tamsagbulag (which had been connected in the past to both Choybalsan and Dziiilnbulag by a narrow-gauge line, now apparently dismantled (?)). This railroad, promoted by the China National Petroleum Corporation (?), also would provide access to the oil field (as to potential new coal fields in the vicinity). And it would open up the most direct route from Eastern Mongolia to China and the Pacific-hopefully in its entirety on uniform gauge. ${ }^{11}$

Oil exploration continues not only at Tamsag (and Dzuiinbayan) in Dornod aimag but also in the central south. The Canadian company Mantower Petroleum, mentioned above, drills in Dornogov aimag, ${ }^{12}$ which is crossed by the Ulaanbaatar Railroad. A joint venture of Mongolneft with Soco International and Canadian Territorial Resources explores the Galba XI field in Omnogov aimag, to the west of Dornogov. Plans for road, railroad and pipeline development appear to be premature in both cases. But there is the potential for connections to several road heads in Inner Mongolia and to the railhead at Bayan Obo, north of Baotou abide, assuming that any oil found there would be exported as well.

Coal Mining. Mongolia has extremely large reserves of coal which remain mostly undeveloped. Established mines, located primarily in the north, are being renovated with international aid since 1991 in order to keep output from declining. ${ }^{13}$ Most of the funding for this purpose has been provided by the international banks and Japan. 14 Inspire of those efforts, coal output has decreased somewhat during the 1990s, 15 with negative consequences for Mongolia's energy balance. 16 Moreover, the prospects for rapid increases in coal production are not very promising according to a World Bank study of 1992:

... To exploit major new anthracite deposits in the southern part of the country will require not just capital for developing mines and the associated

Infrastructure including wateriest but also the building of a railway line to transport the coal to Mongolia's borders. As neither the Soviet Union nor China possesses the capacity to handle Mongolian coal, additional investment would be needed in railway lines and port handling facilities before the coal would become accessible to foreign buyers. Given the 
availability of the low sulfur coal from Chinese and Australian sources at competitive prices, the economics of developing Mongolia's coal reserves for export, as distinct from domestic use, are uncertain. ... ${ }^{17}$

China's promotion of the Tumen River project and specifically the construction of a rail link from Choybalsan to Yirshi may change those prospects. A second though more distant opportunity to develop coal resources relates to the proposed formation of a Northeast Asian power grid. Mongolia's central electricity system currently is tied to the Russian network, and a new system for five western aimags will be linked to it as well. 18 At the present, Mongolia is an importer rather than an exporter of electricity. But the proposed construction of high voltage power lines across its territory would make coal mining for power generation in the east and central south distinct possibilities that might reverse this situation.

Irrespective of such prospects, coal mining apparently is starting in the central south, with foreign direct investment. The Czech Asia Investment Capital Group has reached agreement to develop the Tavan Tolgoi coal field in Omnogov aimag, which will produce coking coal (?). The project involves the construction of a new town for 10,000 families as well as of a rail link (destination unmentioned). 19

Increases in coal production and electricity generation in the north, which are expected to follow the renovation of mines and power stations with foreign aid in preparation for their privatization, 20 should serve to redress the energy balance further. Moreover, given the link to the Russian grid, they may turn Mongolia into an exporter of electric power in the more immediate future, assuming that Russia would want to buy as well as. Sell.

Natural Gas Transit. Mongolia has no known deposits of natural gas. But the most economical transport route from the Lake Baikal region in Russia to the North China plain passes through its territory. Mongolia therefore becomes a party to a Northeast Asian pipeline project which complements the previously mentioned power grid. Both China and Japan are interested in obtaining natural gas from Siberia. According to the Far Eastern Economic Review of 30 October 1997 ,

... The state-run Japan National Oil Corp. recently formed a study team with around 10 Japanese companies to investigate the Kovyktinskoye gas field north of Irrupts. The Japanese group envisions building a pipeline from the field, said to contain 850 billion cubic meters of natural gas, through Mongolia to Beijing, and possibly on to Korea and Japan. Officials caution that the study itself has yet to begin, but they hope to begin piping within 10 years. 21 soon thereafter, it 
became evident that the project had progressed much further than the cautious statements from Japan suggested:

... On November 10 (1997), President Boris Yeltsin and President Jiang signed a framework agreement to lay a natural-gas pipeline from the Siberian fields across 1,000 kilometers of Mongolia to China's Shading province. Extensions would later feed gas to Japan and South Korea.22

. Moreover, the project was referred to as regional, involving Russia, China, Japan, South Korea, and Mongolia.23 Details about the roles of the parties to the agreement, their contributions and returns have not been made public and indeed may not have been formulated yet. One may guess, however, that Mongolia's benefits from the pipeline, which probably would run roughly parallel to the Ulaanbaatar Railroad, would be substantial. The pipeline's construction as well as maintenance would provide opportunities for employment and skill enhancement similar to those of other capital construction projects. Its operation would yield returns, whether in the from of transit fees or profit shares. Its presence ${ }^{1}$ also would facilitate gas imports by Mongolia, especially into Ulaanbaatar and its environs. Pipeline spurs might bring gas to other parts of the urban industrial sector, and so on. Of course, the costs of such developments would be substantial as well and quite possibly difficult to finance. 24

Food Production. Mongolia's urbanization, accelerated by the rapid development of mining during the past two decades, has changed the composition of foods that are being consumed in the aggregate. The animal-based subsistence diet of the countryside, related to extensive animal husbandry, has been replaced in the cities by food intake that is highly dependent on the cultivation of land, directly in the form of food crops and indirectly through feed production for feed lot and dairy operations. Mongolia's climatic conditions seem to render crop crowing an inferior alternative.Nevertheless, the country has opted to develop an import-substituting crop growing sector as a supplement to its traditional trade of animal products for food. After years of disappointing experiences with the sector's performance, the Asian Development Bank is drafting an agricultural program to change this course. 25 the content of the plan has yet to be made public.

Technology transfers from the rest of the world can improve both the comparatively advantageous nomadic animal husbandry and the comparatively disadvantageous crop growing and related operations. In contrast with the development of oil and coal extraction, such transfers involve a great deal of technical assistance, relatively small commitments of foreign capital, and per- 
haps limited improvements in transportation. The opportunities for Northeast Asian regional projects are thus more limited as well. In general, useful experiences are most likely to come from locations anywhere in the world where people have dealt effectively with Mongolia's problems in comparable circumstances.

The critical issue in traditional animal husbandry, e.g., appears to be the preservation of its characteristic mobility in the context of its technical modernization. Possible improvements include not only the greater motorization of the herding families and - preferably- increases in their use of solar energy for cooking, heating, lighting, and so on. In addition, numerous complementary activities need to be mobilized, in particular veterinary services for herd improvement and preservation, the slaughtering, inspection, and refrigeration of meat, the preliminary processing of other animal products such as skins and hides, and transportation of all products to central places.

Changes in all these directions have been aided by foreign technical assistance as well as resource commitments, beginning with grants and loans for road improvements in various parts of the country. Mongolia also obtained a mobile abattoir from the United Kingdom.26 Small amounts of direct foreign investment have improved garment manufacturing as well as meat processing (sausage making). 27 The apparent returns to such advances are meat exports to Russia28 and a growing interest in specialty meats (dog, horse, and yak) elsewhere in East Asia. Improvements in the processing of cashmere and other animal products are less evident.

Foreign investment and technical assistance have been more substantial in crop growing, dairying, and feed lot operations, presumably because they were considered critical for the urban food supply. The ADB in 1991 provided aid for the reorganization of 55 state farms, set up with Soviet support on Soviet patterns, into 300 private (cooperative) farms.29 Subsequent decreases in cropping and in the output of grain, potatoes, and vegetables were attributed to shortages of seed, fertilizer, fuel, and spare parts, all of which used to come from Russia.30 In addition, it was noted that commercial banks refused to lend, creating a shortage of credit.

In response to such problems, efforts at import substitution were made, e.g., in the production of fertilizers.31 In addition, grants and soft loans from Japan provided for improvements in agricultural technology, 32 in milk processing and grain storing, 33 for a horse-meat farm, 34 and for new combines. 35 The country also obtained a Czech (beet) sugar plant which could not be completed in time because of financial constraints on the part of the government.36 Other 
investments in food processing include a joint venture with the Czech firm Asian Investment Capital Group to set up a bakery. 37

The returns to most of these investments have been disappointing so far. The decline in grain production has not been reversed to a significant extent, and there are indications that simultaneously with the overall contraction of crop growing Mongolia has experienced a shift to potato and vegetable farming in terms of both acreage and output shares. 38 such a shift may reflect a better adaptation to the climatic conditions under commercial risk taking, in the absence of previous levels of protection and subsidization. But the overall decline also could point to the for further changes in farm organization, in the direction of family farms which have been comparatively effective everywhere else in the world. One hopes that the ADB directed agricultural development program will shed light on the point in particular.

\section{Conclusion}

Mongolia has been benefiting from international and especially from Northeast Asian economic cooperation in several ways. To begin with, international institutions such as the Asian Development Bank, the International Monetary Fund, and the World Bank have provided technical assistance and financial support to stabilize its economy during the transition from plan to market. The result of this collaboration, which has not been discussed in this paper, has been positive indeed. Mongolia has experienced a transitory decline that was brief as well as mild in comparison with that of Russia and other CMEA economies.39

Mongolia's development interests beyond this transition are being accommodated not only by the same institutions but in particular also by Japan. Most of it's (and other countries') grant and soft loan support has been invested in the improvement of Mongolia's infrastructure and in the renovation of previously built mines and farms, all of them relatively large. In contrast, most of the commercial investment tended to favor small and medium ventures manufacturing and processing so far. However, changes in mining legislation and progress with the privatization of state enterprises have attracted foreign commercial interest and participation in various extractive activities.

Within the context of promoting trade generally, China's cooperation with Mongolia appears to be focused on transport development. It has given Mongolia transit access to the port of Tianjin and proposes to do the same at Tumen area ports, in collaboration with Russia and North Korea. A transit route 
from Eastern Mongolia through Jilin to the Tumen area would be advantageous if it allowed for exports (and imports) those other routes and other ports could not handle. China evidently wants exports of Mongolian oil, but its interest in Mongolian coal, the most likely additional export of the eastern region, is unknown. China's interest in gas pipeline development with transit through Mongolia is shared by Russia, Japan, and South Korea and stands to benefit all at reasonable costs of construction. The same may be said of the proposed development of a Northeast Asian electric power grid, which might offer Mongolia an alternative use for its abundant coal resources.

The paper has not dealt with problems posed by externalities such as pollution and environmental degradation, which are certain to emerge in the process of development. Their control and prevention has been the purpose of official grants by France, the Netherlands, and UNDP.40 they become issues not only in the urban industrial context but in the Mongolian countryside as well. The growth of extensive animal husbandry in response to its privatization has led to such an increase in the animal stock, especially that of goats, that overgrazing becomes a serious threat. Given Mongolia's preference for public ownership of land, 41 the necessary intervention appears to be the proper specification and allocation of private land use rights. One hopes that the ADBs agricultural program will address this important issue, too, and provide the required technical assistance as well.

\section{References and Notes}

1. Asfan Development Bank. Asian Development Outlook, 1997 and 1998. p. 229 ( Table A. 7).

2. Ibid, p. 230 (Table A.8).

3. IMF Staff Country Report, No. 97/92 (October 1997), p. 73 (Table 42).

4. Ibid, p. 74 (Table 43).

5. Economist Intelligence Unit. Country Profile: China/Mongolia, 1997/1998, p.83.

6. IMF Staff Country Report, No. 97/92, p. 74 (Table 43).

7. Ibid, No. 96/24 (March 1996). p.2. Monitor).

8. Far Eastern Economic Review (19 January 1998) (Economic

9. Economist Intelligence Unit. Country Report:China/Mongolia, 1/1998, p.48.

10. Ibid. 
11. Ibid, 1/1996, p.42.

12. Ibid, $1 / 1998$, p.48.

13. EIU. Country Profile: China/Mongolia, 1997/1998, p.79.

14. EIU. Country Report: China/Mongolia, 1/1997, p.55;ii/ 1997,pp.52,56.

15. IMF Staff Country Report, No. 97/92, p. 37.

16. Ibid, pp. 38, 39.

17. World Bank Discussion Papers, No. 145 (January 1992), 'p. 21.

18. EIU. Country Profile: China Mongolia, 1997' 1998, p.77.

19. EIU. Country Report: China Mongolia, HI/1997, pp. 48-49.

20. Ibid.; I/I 998, pp. 50-51 plus note 13.

21. FEER, 30 October 1997. p. 31.

22. Ibid. 26 February 1998, p. 48.

23. EIU. Country Report: China/Mongolia, 1/1998, p.48.

24. The total length of the pipeline has been projected as $3,600 \mathrm{~km}$ and the cost of its construction as $\$ 7$ billion (FEER, 26 February, 1998, p. 48). Other sources have Mentioned even larger amounts. A summary of the Sino-Russian Joint Statement on Relations appears in Beijing Review, 22-28 December 1997. pp. 7-13.

25. EIU. Country Profile: China/Mongolia, 1997/1998, p.80.

26. EIU. Country Report: China/Mongolia, TV/1997, pp. 43-44.

27. EIU. Country Profile: China/Mongolia, 1997/1998, p.83

28.EIU. Country Report: China/Mongolia, IV/1997, pp.46.

29. EIU Country Profile: China/Mongolia, 1997/1998, p.84

30. EIU. Country Report: China/Mongolia, 11/1997, p.57.

31. Ibid, p. 55.

32. Ibid, p. 52.

33. Ibid, p. 59.

34. Ibid, p. 57.

35. Ibid, IV/1997, p. 43.

36. Ibid, 11/1997, p.57.

37. Ibid, IIl/1997,.p.46.

38. Ibid, p. 45.

39. Asian Development Bank, Asian Development Outlook, 1997 and 1998, pp. $223 \mathrm{ff}$.

40. EIU. Country Report: China/Mongolia, 1/1997, p.59, 11/1997, p.52.

41. Ibid, 11/1995, p. 45. 


\section{Sources}

Asian Development Bank. Asian Development Outlook, 1992 Through 1997/1998.

Asian Development Bank. Key Indicators of Developing Asian And Pacific Countries, 1992, 1996, 1997.

Beijing Review, various issues.

Economist Intelligence Unit Country Profile: China/Mongolia, 1997/1998.

Economist Intelligence Unit. Country Report:-China/Mongolia, 1/1992 through $1 / 1998$.

Far Eastern Economic Review, various issues.

International Monetary Fund. The Mongolian People's Republic: Toward a Market Economy; Occasional Paper 79 (April 1991).

International Monetary Fund. Mongolia - Background Paper, No. 95/11 (1995).

International Monetary Fund. Mongolia - Background Material, No. 96/24(1996).

International Monetary Fund. Mongolia - Recent Economic Developments; IMF Staff Country Report No. 97/92 (1997).

World Bank. Developing Mongolia; World Bank Discussion Papers No. 145(1992). 